\title{
O PRINCÍPIO DA DIGNIDADE DA PESSOA HUMANA NO ORDENAMENTO
} JURÍDICO BRASILEIRO*

\author{
Eloy Pereira Lemos Junior† \\ Ana Flávia Brugnarał
}

RESUMO: O presente trabalho teve como escopo demonstrar a importância e a magnitude do princípio da dignidade da pessoa humana no ordenamento jurídico brasileiro. Com raízes constitucionais, o princípio da dignidade da pessoa humana encontra-se em um dos patamares mais elevados de nosso Direito, sendo um dos fundamentos da República Federativa do Brasil e funcionando como um princípio onde todas as demais normas tiram validade, possuindo um papel de inconteste grandeza. Assim, ao prever a dignidade da pessoa humana no texto da Constituição Federal de 1988, o Estado colocou o ser humano no centro de todo o ordenamento jurídico, passando os indivíduos a serem considerados como sujeitos dotados de direitos fundamentais, os quais devem ser compatíveis com a dignidade da pessoa humana, sendo qualquer outra norma contrária a tais preceitos dotada de inconstitucionalidade. Outrossim, é que, antes de adentrar ao tema proposto desta linha de estudo, esclarece-se que foi utilizado o método científico da pesquisa qualitativa e bibliográfica.

PAlAVRAS-CHAVE: Direitos Fundamentais. Princípio. Dignidade da Pessoa Humana.

\section{PRINCIPLE OF THE DIGNITY OF THE HUMAN PERSON IN BRAZILIAN LAW}

\begin{abstract}
This work was scope to demonstrate the importance and magnitude of the principle of human dignity in the Brazilian legal system. With constitutional roots, the principle of human dignity is in one of the highest levels of our law, one of the foundations of the Federative Republic of Brazil and working as a principle on which all other rules take validity, having a paper undisputed greatness. Thus, by providing for the dignity of the human person in the text of the Constitution of 1988, the state put the individual at the center of the whole legal system, through individuals to be considered as subjects endowed with fundamental rights, which should be compatible with the dignity of the human person, and any other standard contrary to such precepts gifted unconstitutional. Also, it is that , before entering the proposed theme of this line of study, it is clarified that we used the scientific method of qualitative and literature.
\end{abstract}

KEY WORDS: Fundamental Rights. Principle. Dignity of Human Person.

\footnotetext{
* Artigo recebido em Artigo recebido em 16/12/2016 e aprovado em 26/12/2016

$\dagger$ Doutor em direito pela UFMG (2007), possui mestrado e especializações. Foi bolsista CAPES (2005) na Universidade de Lisboa, atualmente bolsista FUNDEP-UFMG (desde 2013). Avaliador de cursos de direito pelo INEP-MEC (desde 2010). Atualmente, é professor titular do mestrado e da graduação da

Universidade de Itaúna (MG), titular na graduação da UEMG, da FACED - Divinópolis (MG), UNIPAC, UNI$\mathrm{BH}$ e na especialização da UNA-BH. Tem experiência na área de direito, com ênfase em direito empresarial. Conselheiro editorial e parecerista de revistas especializadas em direito, palestrante, orientador de trabalhos científicos, participante de NDE - Núcleo Docente Estudante e de bancas diversas.

¥Atualmente é Estudante de Direito do Fundação Universidade de Itaúna
} 


\section{INTRODUÇÃO}

O princípio da dignidade da pessoa humana é consagrado pela Constituição da República Federativa do Brasil de 1988, em seu artigo $1^{\circ}$, inciso III, como sendo um dos fundamentos do Estado Democrático de Direito, o que denota a importância que o princípio em questão possui em nosso ordenamento jurídico atual.

Neste sentido, o princípio da dignidade da pessoa humana encontra-se presente em todos os ramos e desdobramentos do Direito brasileiro, não podendo jamais ser deixado de lado, tendo em vista que é a partir da dignidade da pessoa humana que passam a ser garantidos a todos os indivíduos, pelo simples fato de terem nascido com vida e sem o preenchimento de nenhuma condição específica, os direitos humanos que lhes são inerentes.

Assim, a partir do momento em que o Estado passou a prever a dignidade da pessoa humana no bojo da Constituição Federal de 1988, ficou determinado que nenhuma pessoa poderia viver em condições desprezíveis, pois tal fato vai de encontro com sua dignidade, maculando-a e ferindo, terminantemente, sua condição nata de ser humano digno.

Desse modo, o princípio da dignidade da pessoa humana nos remete aos chamados direitos fundamentais, que nada mais são do que os direitos humanos positivados no ordenamento jurídico. Os direitos fundamentais são a concretização do princípio da dignidade da pessoa humana na medida em que aqueles garantem aos indivíduos o exercício dos direitos que hes são próprios pelo simples fato de serem seres humanos. Dessa forma, o direito à vida, à liberdade, à saúde, à educação, etc. passam a ser direito de todos os cidadãos, independente de cor, sexo e classe social, por estarem os seres humanos no centro do sistema jurídico, sendo isso compatível com a dignidade humana.

É cediço que no decorrer da história mundial a dignidade humana sofreu inúmeras afrontas, sendo que chamamos a atenção ao período da Segunda Guerra Mundial (1939/1945), onde o objetivo dos nazistas eram exterminar os judeus, fazendo com que existisse a chamada raça ariana, que consistia em um ideal de pureza racial. 
Revista da Faculdade de Direito-RFD-UERJ - Rio de Janeiro, n. 31, jun. 2017

Ora, tais barbaridades e crueldades não podem ser toleradas nos dias atuais, sendo inteiramente oposto ao que preconiza o princípio da dignidade da pessoa humana, que garante a todos os indivíduos uma existência decente e compatível com os direitos fundamentais.

Lado outro, cumpre ressaltar que todas as regras constantes no sistema jurídico brasileiro devem estar de acordo com o princípio basilar da dignidade da pessoa humana, sob pena de atentarem contra os direitos fundamentais e serem, portanto, inconstitucionais.

Assim, é patente a importância do princípio da dignidade da pessoa humana, sendo que mesmo se este não fosse previsto expressamente em nossa Carta Magna, o Estado teria que garanti-lo aos cidadãos, tendo em vista que a dignidade é um direito inerente à condição de ser humano, não podendo os indivíduos jamais ficar a mercê das arbitrariedades e truculências estatais.

\section{OS PRINCÍPIOS E O PRINCÍPIO DA DIGNIDADE DA PESSOA HUMANA}

Antes de mais nada, se faz oportuno destacar acerca de qual seria o conceito de princípio e sobre a magnitude e peso dos mesmos em nosso ordenamento jurídico, abarcando, especificamente, a dignidade da pessoa humana, princípio elementar de todo o Direito brasileiro, expressamente consagrado em nossa Constituição Federal.

Assim sendo, os princípios são preceitos ou conjeturas considerados universais que definem as regras pela qual uma sociedade civilizada deve se orientar. São normas fundamentais, basilares, que possuem efeitos inquestionáveis, constituindo-se de teorias principais do Direito, estando relacionados àqueles valores básicos e urgentes da sociedade.

Depreende-se desse significado que a palavra princípio nos dá a ideia de começo, onde tudo se inicia. Assim, para o Direito e, principalmente, para o Direito Constitucional, tal vocábulo, quando esculpido dentro do contexto dos princípios 
Revista da Faculdade de Direito-RFD-UERJ - Rio de Janeiro, n. 31, jun. 2017

fundamentais, diz respeito ao início de todo sistema jurídico, afinal se trata de toda a base em que se sustenta e desenvolve.

Na obra de Ruy Samuel Espíndola (1998, p. 76), a natureza dos princípios constitucionais é definida como sendo:

Conteúdos primários diretores do sistema jurídico-normativo fundamental de um Estado. Dotados de originalidade e superioridade material sobre todos os conteúdos que formam o ordenamento constitucional, os valores firmados pela sociedade são transformados pelo Direito em princípios.

Dessa forma, os princípios são normas gerais aplicados a determinados comportamentos, devendo, por essa razão, serem visualizados como forma de interpretação e integração das leis em nosso sistema jurídico.

O poder da normatividade dos princípios é a norma-chave de todo o sistema jurídico, cuja importância encontra-se, essencialmente, na integração das normas e no desenvolvimento das mesmas, visto que os princípios possuem eficácia plena e aplicabilidade imediata.

O mestre José Joaquim Gomes Canotilho (2002, p. 1149) define os princípios da seguinte forma:

Consideram-se princípios jurídicos fundamentais os princípios historicamente objetivados e progressivamente introduzidos na consciência jurídica e que encontram uma recepção expressa e/ou implícita no texto constitucional. Pertencem à ordem jurídica positiva e constituem um importante fundamento para a interpretação, integração, conhecimento e aplicação do direito positivo.

Cita-se, ainda, o que pensa Carlos Maximiliano (1997, p. 241) sobre os princípios:

Todo conjunto harmônico de regras positivas é apenas o resumo, a síntese, o substratum de um complexo de altos ditames, o índice materializado de um sistema orgânico, a concretização de uma doutrina, série de postulados que enfeixam princípios superiores. Constituem estes as diretivas ideias do hermeneuta, os pressupostos científicos da ordem jurídica. Se é deficiente o repositório de normas, se não oferece, explícita ou implicitamente, e nem sequer por analogia, o meio de regular ou resolver um caso concreto, o estudioso, o magistrado ou o funcionário administrativo como que renova, 
em sentido inverso, o trabalho do legislador: este procede de cima para baixo, do geral ao particular; sobe aquele gradativamente, por indução, da ideia em foco para outra mais elevada, prossegue em generalizações sucessivas, e cada vez mais amplas, até encontrar a solução colimada.

Roque Antônio Carrazza (2010, p. 31) conceitua os princípios como sendo:

Um enunciado lógico implícito ou explícito, que, por sua grande generalidade, ocupa posição de preeminência nos vastos quadrantes do Direito e, por isso mesmo, vincula, de modo inexorável, o entendimento e a aplicação das normas jurídicas que com ele se conectam.

Temos, também, o conceito de princípios por Celso Antônio Bandeira de Mello (2003, p. 817-818):

\begin{abstract}
Princípio [...] é, por definição, mandamento nuclear de um sistema, verdadeiro alicerce dele, disposição fundamental que se irradia sobre diferentes normas compondo-lhes o espírito e servindo de critério para sua exata compreensão e inteligência, exatamente por definir a lógica e a racionalidade do sistema normativo, no que lhe confere a tônica e lhe dá sentido harmônico.
\end{abstract}

Ademais, Miguel Reale (1999, p. 60) define princípios como sendo "verdades ou juízos fundamentais, que servem de alicerce ou de garantia de certeza a um conjunto de juízos, ordenados em um sistema de conceitos relativos a dada porção da realidade".

Assim, dúvidas não pairam sobre o patamar que os princípios ocupam, sendo inconteste que eles funcionam como fonte norteadora, imutável e basilar de todo nosso ordenamento jurídico.

Nesse sentindo, não há como negar a importância que o princípio da dignidade da pessoa humana possui, sendo reconhecido como princípio constitucional fundamental pela nossa Constituição Federal de 1988.

Os mencionados princípios constitucionais fundamentais encontram-se elencados nos artigos $1^{\circ}$ ao $4^{\circ}$ da Carta Magna. São os assim também chamados de preceitos básicos da organização constitucional, sendo que o princípio da dignidade da pessoa humana está inserido neste rol, conforme consta do artigo $1^{\circ}$, inciso III, do Diploma Constitucional. 
Revista da Faculdade de Direito-RFD-UERJ - Rio de Janeiro, n. 31, jun. 2017

Dignidade, nas palavras de Alexandre de Moraes (2004, p. 52), é:

\begin{abstract}
Um valor espiritual e moral atinente à pessoa, que se manifesta singularmente na autodeterminação consciente e responsável da própria vida, e que traz consigo a pretensão ao respeito por parte das demais pessoas, constituindo-se um mínimo invulnerável que todo estatuto jurídico deve assegurar, de modo que, somente excepcionalmente, possam ser feitas limitações ao exercício dos direitos fundamentais, mas sempre sem menosprezar a necessária estima que merecem todas as pessoas enquanto serem humanos.
\end{abstract}

Dessa forma, o princípio da dignidade da pessoa humana determina que ninguém poderá violar os direitos do homem, cabendo ao Estado o amparo desses direitos e a garantia do exercício das liberdades individuais.

Portanto, ao reconhecer a dignidade da pessoa humana como princípio constitucional fundamental, o Estado determina que todo o sistema jurídico brasileiro deve estar a ela subordinado, sendo, outrossim, forma diretora da ciência do Direito.

\title{
3. O CONCEITO DO PRINCÍPIO DA DIGNIDADE DA PESSOA HUMANA
}

A expressão dignidade vem do latim, dignitas, que significa tudo aquilo que merece respeito, consideração, reverência, mérito, importância, acatamento, ou estima. Assim, a dignidade é atributo de quem é honrado e decente, consistindo como uma forma de valorização do ser humano.

O dicionário Houaiss e Villar (2004, p. 248) define a palavra dignidade como sendo a "consciência do próprio valor; honra; modo de proceder que inspira respeito; distinção; amor próprio".

Desse modo, a enorme importância de se garantir a dignidade a cada ser humano fez com que a Constituição Federal de 1988 trouxesse, pela primeira vez na história do Brasil, a dignidade da pessoa humana como fundamento do Estado brasileiro.

Salientamos que antes da atual Carta Política, o Brasil sofreu um governo marcado pelo desrespeito e pelo desprezo do ser humano, com milhares de pessoas sendo castigadas, maltratadas, desaparecidas e mortas porque simplesmente não concordavam com a ideologia e propósitos então predominantes. 
Revista da Faculdade de Direito-RFD-UERJ - Rio de Janeiro, n. 31, jun. 2017

Sendo assim, ao prever a dignidade da pessoa humana como característica essencial, o Estado reconheceu a primazia do ser humano como titular de direitos e deveres, sendo este o centro e o fim de todo ordenamento jurídico.

A prerrogativa da dignidade da pessoa humana é um valor básico, constitucionalmente falando, um valor máximo e absoluto, sendo certo afirmar que a ofensa a tal princípio se tornou um impedimento irremovível, pois o zelo pela dignidade humana é um valor supremo, soberano e essencial cultivado pela Constituição Federal de 1988.

Ocorre que a Carta Magna, a Declaração Universal dos Direitos Humanos, e tampouco qualquer outro documento internacional não determina o conceito do que vem a ser a dignidade da pessoa humana, deixando esta tarefa a cargo do entendimento dos doutrinadores, juristas e tribunais do mundo inteiro.

Para Kant, a dignidade do ser humano se baseia no caráter racional da pessoa, sendo esta digna por natureza, pelo simples fato de ter nascido com vida. A dignidade, neste contexto, seria uma qualidade que o ser humano possui, sem qualquer condição prévia, e não uma concessão estatal. Se a dignidade humana é atributo e não permissão por parte do Estado, não interessa se determinado ordenamento jurídico a reconhece ou não.

Este também é o entendimento de Ingo WolfgangSarlet (2009, p. 47):

Assim, vale lembrar que a dignidade evidentemente não existe apenas onde é reconhecida pelo Direito e na medida que este a reconhece, já que constitui dado prévio, no sentido de preexistente e anterior a toda experiência especulativa.

Na mesma esteira, temos as conclusões de José Afonso da Silva (2007, p. 146):

Correlacionados assim os conceitos, vê-se que a dignidade é atributo intrínseco, da essência, da pessoa humana, único ser que compreende um valor interno, superior a qualquer preço, que não admite substituição equivalente. Assim a dignidade entranha-se e se confunde com a própria natureza do ser humano. 
Revista da Faculdade de Direito-RFD-UERJ - Rio de Janeiro, n. 31, jun. 2017

Dessa forma, é imperioso reconhecer que a dignidade da pessoa humana tem familiar afinidade com o direito natural. Se tivermos em mente que o direito natural é aquele que surge com os seres humanos, a dignidade humana faz parte deles, tendo em vista que o homem possui aptidões próprias e poder de inteligência já ao ser concebido, o que o distingue dos demais seres que habitam o planeta Terra, sendo, portanto, forçoso afirmar que todos os seres humanos, ao virem ao mundo, são idênticos em dignidade, sendo que o que os diferenciam, posteriormente, é a situação sociocultural e econômica no qual estão implantados.

Entretanto, ainda que a expressão dignidade humana admita múltiplos significados, estes possuem um mesmo embasamento em comum, qual seja, a proteção aos direitos básicos dos seres humanos.

As diferenças entre os significados podem surgir de uma coletividade para outra, de um ambiente para outro, de um meio social para outro, uma vez que são formados por controles religiosos, éticos, filosóficos e morais. Numa sociedade, ao referido termo pode ser atribuído um significado, que poderá tornar-se mais aberto ou menos fechado, de indivíduo para indivíduo, dentro desse mesmo conjunto social.

Assim, é notório que o princípio da dignidade da pessoa humana possui um significado muito abarcante, existindo, por essa razão, um enorme problema de se estabelecer um conceito jurídico estagnado a seu respeito. Sua acepção e limitação são amplas, tendo em vista conglomerar vários entendimentos e conceitos, sendo que seu reconhecimento e seu amparo pelo Direito é decorrência do progresso do pensamento do ser humano, muito embora seja o reconhecimento desnecessário por tratar-se de um valor que preexistiu ao homem, conforme já mencionado alhures.

É importante ressaltar, ainda, que o objeto de proteção à dignidade estende-se a qualquer ser humano, independentemente da idade, sexo, origem, cor, condição social, capacidade de entendimento e autodeterminação ou status jurídico, constituindo, outrossim, como um valor comum, sendo composto por uma série de direitos partilhados por todos os seres, em idêntica dimensão. Por essa razão, não é possível falar-se em mais ou menos dignidade, pelo menos na acepção aqui atribuída ao termo, de conjunto aberto e universal de direitos existenciais. Dessa forma, podemos afirmar 
Revista da Faculdade de Direito-RFD-UERJ - Rio de Janeiro, n. 31, jun. 2017

que o ser humano - apenas por sê-lo - não perde a sua dignidade, por mais indigna, vil, desprezível ou infame que seja o seu comportamento.

Por óbvio, o princípio da dignidade da pessoa humana implica no reconhecimento da igualdade entre todos os seres humanos, sendo esta, portanto, uma de suas bases, o que significa afirmar que todas as pessoas são análogas em direitos e obrigações, independentemente de qualquer característica pessoal que lhe possa favorecer.

A outra base da dignidade é a liberdade. É esta, em seu sentido mais abrangente, que admite aos seres humanos praticar inteiramente os seus direitos existenciais, pelo simples fato de terem sido concebidos com vida. O ser humano precisa de liberdade para pensar, escolher, planejar, falar, refletir, ponderar, manifestar suas opiniões, etc., não podendo o Estado mitigar esse direito.

Para ilustrar, temos os dizeres da Declaração Universal dos Direitos Humanos, a qual consagra, em seu artigo $1^{\circ}$, a liberdade e igualdade como bases da dignidade humana, nos seguintes termos:

Art. $1^{\text {o: }}$ Todas as pessoas nascem livres e iguais em dignidade e direitos. São dotadas de razão e consciência e devem agir em relação umas às outras com es pírito de fraternidade.

\section{O PRINCÍPIO DA DIGNIDADE DA PESSOA HUMANA E OS DIREITOS FUNDAMENTAIS}

Os Direitos Fundamentais, de acordo com o entendimento clássico, são mecanismos de proteção do ser humano diante da atuação estatal. Eles estão elencados na Constituição Federal de 1988, não se limitando ao rol de seu artigo $5^{\circ}$, estando, assim, espalhados, por toda Carta Magna.

Desse modo, a própria Constituição Federal estabelece várias terminologias a fim de identificar os direitos fundamentais: direitos humanos, direitos e garantias individuais, direitos e liberdades constitucionais, direitos e garantias fundamentais, 
Revista da Faculdade de Direito-RFD-UERJ - Rio de Janeiro, n. 31, jun. 2017

direitos e liberdades fundamentais e, finalmente, direitos fundamentais da pessoa humana.

Essas expressões, quase sempre tidas como sinônimas, não se confundem, tendo em vista que a locução direitos fundamentais é utilizada para definir os direitos objetivamente vigentes em uma ordem jurídica real, e a expressão direitos humanos é empregada para se referir aos direitos dos seres humanos constantes em documentos de cunho de Direito Internacional. Para simplificar, o correto seria dizer que os direitos fundamentais são os direitos humanos positivados em nosso ordenamento jurídico.

Na visão de Ingo Wolfgang Sarlet (2007, p. 85):

Direitos fundamentais são, portanto, todas aquelas posições jurídicas concernentes às pessoas que, do ponto de vista do direito constitucional positivo, foram, por seu conteúdo e importância (fundamentalidade em sentido material), integradas ao texto da Constituição e, portanto, retiradas da esfera de disponibilidade dos poderes constituídos (fundamentalidade formal), bem como as que, por seu conteúdo e significado, possam lhes ser equiparados, agregando-se à Constituição material, tendo, ou não, as sento na Constituição formal.

Dimitri Dimoulis (2007, p. 54) segue este mesmo raciocínio:

Direitos fundamentais são direito público-subjetivos de pessoas (físicas ou jurídicas), contidos em dispositivos constitucionais e, portanto, que encerram caráter normativo supremo dentro do Estado, tendo como finalidade limitar o exercício do poder estatal em face da liberdade individual.

Neste contexto, torna-se evidente que a Constituição Federal de 1988, ao reconhecer os direitos fundamentais, possuía o escopo de proteger a dignidade da pessoa humana, sendo certo afirmar que aqueles encontram seu fundamente direto e imediato nesta. Assim, podemos afirmar que o direito à liberdade, à vida, à igualdade, dentre tantos outros, são desdobramentos do princípio da dignidade da pessoa humana.

Dessa forma, o princípio em questão nada mais é do que o fundamento contemporâneo dos direitos fundamentais e que tem como sustentáculo axiológico o princípio do universalismo dos direitos humanos.

Kildare Gonçalves Carvalho explica que (2007, p. 549): 
Revista da Faculdade de Direito-RFD-UERJ - Rio de Janeiro, n. 31, jun. 2017

\begin{abstract}
A dignidade da pessoa humana é o fundamento de todo o sistema dos direitos fundamentais, no sentido de que estes constituem exigências, concretizações e desdobramentos da dignidade da pessoa e que combase nesta é que devem aqueles ser interpretados.
\end{abstract}

No mesmo sentido, afigura-se digna de registro a manifestação de Ingo Wolfgang Sarlet (2008, p. 88-89):

A dignidade da pessoa humana, na condição de valor fundamental atrai o conteúdo de todos os direitos fundamentais, exige e pressupõe o reconhecimento e proteção dos direitos fundamentais de todas as dimensões. Assim, sem que se reconheçam à pessoa humana os direitos fundamentais que lhes são inerentes, em verdade estar-se-á negando-lhe a própria dignidade.

E continua Ingo Wolfgang Sarlet (2004, p. 79) em outra obra:

Na dignidade da pessoa humana, do qual seriam concretizações, constata-se que os direitos e garantias fundamentais podem ser reconduzidos de alguma forma à noção de dignidade da pessoa humana, já que todos remontam à ideia de proteção e desenvolvimento das pessoas.

Sob a ótica de José Afonso da Silva (2007, p. 38) "a dignidade da pessoa humana é um valor supremo que atrai o conteúdo de todos os direitos fundamentais do homem, desde o direito à vida".

Assim, é inconteste que o princípio da dignidade da pessoa humana funciona como valor absoluto, unindo os direitos fundamentais e o fundamento do Estado Democrático de Direito. Tal unidade é obtida em virtude da essencialidade dos direitos fundamentais, perante os outros direitos previstos na Carta Magna, não sendo a inserção desses direitos colocados de maneira ocasional, mas sim tendo como alvo o reconhecimento do ser humano como pessoa autônoma e sua dignidade tida como princípio fundamental e supremo da ordem constitucional.

Correto se faz afirmar que a Constituição Federal de 1988 elevou o princípio da dignidade da pessoa humana ao status de norma rainha dos direitos fundamentais, 
Revista da Faculdade de Direito-RFD-UERJ - Rio de Janeiro, n. 31, jun. 2017

situando-a no mais elevado escalão de hierarquia jurídica do sistema constitucional, como princípio fundamental da República Federativa do Brasil.

Assim sendo, o princípio da dignidade da pessoa humana é tido como um princípio-valor que está no topo de nosso ordenamento jurídico, conferindo unidade ao conjunto de regras relativas aos direitos fundamentais, agindo como um componente fundante e diretor de tais direitos, servindo de base para aplicação, interpretação e integração, não apenas dessas pretensões constitucionais, mas de todo o sistema jurídico brasileiro.

\section{O PRINCÍPIO DA DIGNIDADE DA PESSOA HUMANA COMO FUNDAMENTO DA REPÚBLICA FEDERATIVA DO BRASIL}

A Constituição Federal de 1988, no título "Dos Princípios Fundamentais”, em seu artigo $1^{\circ}$, inciso III, dispõe, in verbis:

\footnotetext{
Art. $1^{\circ}$ - A República Federativa do Brasil, formada pela união indissolúvel dos Estados e Municípios e do Distrito Federal, constitui-se em Estado Democrático de Direito e tem como fundamento:

$[\ldots]$

III - a dignidade da pessoa humana.
}

No artigo mencionado acima, a Carta Política garante a dignidade do homem e da mulher, na qualidade de pessoas concretas, em suas vidas reais e corriqueiras, considerando suas existências como indomável, irreduzível e insubstituível e cujos direitos fundamentais a Constituição Federal elenca e assegura.

Sabido é que a pessoa humana não é um ser irreal e abstrato. Neles estão presentes todas as faculdades da humanidade, existindo em todos os seres humanos, indistintamente, características boas e ruins, as quais não são levadas em consideração para aferição da dignidade individual de cada um.

Assim sendo, o princípio da dignidade da pessoa humana é um dos que tem maior influência no ordenamento jurídico brasileiro, dos que tem maior importância perante os demais princípios e normas constitucionais e infraconstitucionais, se 
Revista da Faculdade de Direito-RFD-UERJ - Rio de Janeiro, n. 31, jun. 2017

revelando como princípio basilar e essencial. Suas consequências alcançam todo o ordenamento jurídico, uma vez que se encontra entre os princípios fundamentais do Direito Brasileiro.

A Constituição Federal de 1988, que entrou em vigor depois de um longo período autoritário e ditatorial, passou a estabelecer um fundamento ético comum para todas as pessoas dentro de uma mesma ordem jurídica. Na procura de efetividade ao vasto elenco de direitos garantidos, principalmente aos direitos fundamentais, estabelecidos em seu artigo $5^{\circ}$, a Carta Magna passou a ser um marco de ruptura de paradigmas, passando por cima de moldes até então vigentes no que tange à proteção e defesa da dignidade do ser humano como titular de direitos.

Neste contexto, Ingo Wolfgang Sarlet (2001, p. 103) foi muito sábio ao afirmar:

O constituinte de 1988, além de ter tomado uma decisão fundamental a respeito do sentido, da finalidade e da justificação do exercício do poder estatal e do próprio Estado, reconheceu categoricamente que é o Estado que existe em função da pessoa humana, e não o contrário, já que o ser humano constitui a finalidade precípua e não meio da atividade estatal.

Ao reconhecer a dignidade da pessoa humana como fundamento do Estado Democrático de Direito, o Estado passou a vê-la como um valor absoluto e supremo em nosso sistema jurídico, assumindo, outrossim, a obrigação de zelar pelos valores mais importantes dos seres humanos.

Dessa forma, o fato de a dignidade humana ter sido colocada no andar mais alto da Constituição Federal de 1988 significa que o Estado, de modo decisivo, deixou de enxergar a pessoa humana como mero artifício, concebendo a ideia do ser humano como sujeito repleto de garantias e de direitos que necessitam de reconhecimento e amparo.

No entendimento de Luís Roberto Barroso (2001, p. 26-27), a dignidade da pessoa humana:

Representa a superação da intolerância, da discriminação, da exclusão social, da violência, da incapacidade de aceitar o outro, o diferente, na plenitude de sua liberdade de ser, pensar e criar. 
Revista da Faculdade de Direito-RFD-UERJ - Rio de Janeiro, n. 31, jun. 2017

No mesmo sentido, temos os dizeres de Ingo Wolfgang Sarlet (2011, p. 73):

\begin{abstract}
Temos por dignidade da pessoa humana a qualidade intrínseca e distintiva reconhecida em cada ser humano que o faz merecedor do mesmo respeito e consideração por parte do Estado e da comunidade, implicando, neste sentido, um complexo de direitos e deveres fundamentais que assegurem a pessoa tanto contra todo e qualquer ato de cunho degradante e desumano, como venham a lhe garantir as condições existenciais mínimas para uma vida saudável, além de propiciar e promover sua participação ativa e corresponsável nos destinos da própria existência e da vida em comunhão com os demais seres humanos mediante o devido respeito aos demais seres que integram a rede da vida.
\end{abstract}

Portanto, torna-se imperioso afirmar que a partir da Carta Política de 1988, que consagrou a dignidade humana como fundamento da República Federativa do Brasil, o Estado passou a enxergar, com primazia, os direitos dos homens, em todas as suas dimensões e extensões. O Estado deixou de ter um pensamento patrimonialista para dar lugar a uma estrutura voltada para a proteção e bem estar do ser humano, passando as pessoas a serem o núcleo do mundo jurídico e a prioridade que explica o sentido de ser do Direito.

\title{
6. O CARÁtER RELATIVO DO PRINCÍPIO DA DIGNIDADE DA PESSOA HUMANA
}

Por ser um dos fundamentos da República Federativa do Brasil, conforme determina o artigo $1^{\circ}$, inciso III, da nossa Carta Magna, o princípio da dignidade da pessoa humana é tido como um valor pré-constituinte e de hierarquia mais elevada que a própria Constituição, sendo, sem sombra de dúvidas, o valor com maior importância para o Estado Democrático de Direito.

Segundo Paulo Bonavides (2001, p. 233) "nenhum princípio é mais valioso para compendiar a unidade material da Constituição que o princípio da dignidade da pessoa humana”.

Da mesma forma, Flávia Piovesan (2004, p. 92) afirma que: 
Revista da Faculdade de Direito-RFD-UERJ - Rio de Janeiro, n. 31, jun. 2017

\begin{abstract}
É no valor da dignidade da pessoa humana que a ordem jurídica encontra seu próprio sentido, sendo seu ponto de partida e seu ponto de chegada, na tarefa de interpretação normativa. Consagra-se, assim, dignidade da pessoa humana como verdadeiro super princípio a orientar o Direito Internacional e o Interno.
\end{abstract}

Também nesta esteira, a fim de proporcionar à dignidade da pessoa humana umstatus de princípio basilar, sustentáculo e fonte de todo ordenamento jurídico brasileiro, temos a opinião do Supremo Tribunal Federal sobre o tema:

[...] o postulado da dignidade da pessoa humana, que representa - considerada a centralidade desse princípio essencial $\left(\mathrm{CF}\right.$, art. $1^{\circ}$, III) - significativo vetor interpretativo, verdadeiro valor-fonte que conforma e inspira todo o ordenamento constitucional vigente em nosso País e que traduz, de modo expressivo, um dos fundamentos em que se assenta, entre nós, a ordem republicana e democrática consagrada pelo sistema de direito constitucional positivo [...]. (HC 95464, Relator(a): Min. CELSO DE MELLO, Segunda Turma, julgado em 03/02/2009, DJe-048 DIVULG 12-03-2009 PUBLIC 1303-2009 EMENT VOL-02352-03 PP-00466).

Sendo assim, no Brasil, o princípio da dignidade da pessoa humana é tido, de forma geral, como um princípio absoluto, o qual não permite nenhuma relativização ou ponderação ao ser comparado com os demais princípios, tendo em vista que para certos juristas a dignidade humana possui primazia suprema em nosso sistema jurídico, servindo como um importante vetor na ponderação de interesses constitucionais, sendo ainda que os demais princípios fundamentais retiram a sua validade do princípio maior da dignidade da pessoa humana.

Entretanto, num olhar menos conservador, é admissível, sim, relativizar o princípio da dignidade humana e ponderá-lo com outros princípios, também constitucionais, tais como legalidade, democracia, soberania do Estado e do povo, etc.

Assim sendo, numa ponderação com outros princípios constitucionais fundamentais, a dignidade humana não possui essencialmente preferência, tendo em vista que os outros princípios fundamentais, assim como a dignidade humana, são princípios que tem que ser, primeiramente, existentes, certos e válidos, o que permite a eles terem a mesma hierarquia e gradação, assim como terem a mesma importância, peso e qualidade do princípio da dignidade da pessoa humana. Por essa razão, numa 
Revista da Faculdade de Direito-RFD-UERJ - Rio de Janeiro, n. 31, jun. 2017

visão atual, o princípio da dignidade da pessoa humana pode, em determinados casos concretos, ser sobreposto pelos demais princípios constitucionais.

Dessa forma, mesmo diante do valor de inconteste magnitude, a dignidade da pessoa humana não pode ser considerada como um princípio que possui aplicabilidade incondicional, ou seja, que sempre, sem nenhuma exceção, prevalecerá sobre qualquer outro princípio.

Correto se faz asseverar, portanto, que para os direitos de grande valor, como é o caso do princípio da dignidade da pessoa humana, também existem barreiras. Isso significa que quando tal princípio é contraposto a outros princípios fundamentais também resguardados pela Constituição Federal e que possuem a mesma hierarquia jurídica daquele, a dignidade humana poderá ser relativizada. Assim, em caso de conflitos entre esses princípios constitucionais, apenas poderá ser determinada a importância preponderante de cada um deles no caso concreto, avaliando-se as particularidades de certas circunstâncias.

Já decidiu o Egrégio Supremo Tribunal Federal:

Não há, no sistema constitucional brasileiro, direitos ou garantias que se revistam de caráter absoluto, mesmo porque razões de relevante interesse público ou exigências derivadas do principio de convivência das liberdades legitimam, ainda que excepcionalmente, a adoção, por parte dos órgãos estatais, de medidas restritivas das prerrogativas individuais ou coletivas, desde que respeitados os termos estabelecidos pela própria Constituição. (STF - RJT 173/807-808, Rel. Min. CELSO DE MELLO, Pleno).

Nesta mesma esteira, Gilmar Mendes (1993, p. 105-109):

O princípio da dignidade da pessoa comporta graus de relativização, e o fato de que, sob determinadas condições, com um alto grau de certeza, preceda a todos os outros princípios, is so não lhe confere caráter absoluto, significando apenas que quase não existem razões jurídico-constitucionais que não se deixem comover para uma relação de preferência em favor da dignidade da pessoa sob determinadas condições.

Desse modo, para ilustrar a mitigação do princípio da dignidade da pessoa humana, temos o caso do feto anencéfalo, no qual o Supremo Tribunal Federal, em 
Revista da Faculdade de Direito-RFD-UERJ - Rio de Janeiro, n. 31, jun. 2017

julgamento memorável ${ }^{4}$, concedeu a realização do aborto por diversos motivos, mas principalmente em razão do princípio da dignidade da pessoa humana, relativamente à gestante, tendo em vista que a esta seria causado um enorme sofrimento, quase sempre desnecessário. Note-se, neste caso, a mitigação do princípio da dignidade da pessoa humana em relação ao feto.

Por outro lado, é mais do que evidente que os princípios constitucionais, como no caso do princípio da dignidade da pessoa humana, possuem primazia ao serem comparados com os princípios infraconstitucionais, afinal estes retiram a sua validade precípua devido à existência daqueles. Todavia, em que pese o princípio da dignidade humana ter um valor indiscutível, o qual prevalece na maioria esmagadora dos casos práticos como importância soberana a ser realizada, é um princípio de natureza relativa, assim como todos os outros, estando, outrossim, sujeitos à ponderação quando confrontado com os demais princípios de valores análogos.

\section{O PRINCÍPIO DA DIGNIDADE DA PESSOA HUMANA E OS TRATADOS DE DIREITO INTERNACIONAL}

A dignidade da pessoa humana pode ser vista com muita constância nos preâmbulos de tratados internacionais, sendo que tal fato reforça o peso que o referido princípio tem em comparação com os outros direitos humanos, servindo, outrossim, como justificativa para a própria essência destes.

É sabido que o século XX foi marcado pelas nefastas crueldades advindas, principalmente, da Segunda Guerra Mundial, a qual atentou contra a humanidade de uma forma trágica e impiedosa, havendo violação de direitos humanos sem precedentes. Foi neste contexto que, após os absurdos e atrocidades cometidos contra a dignidade da pessoa humana, esta ganhou extrema importância, sendo consagrada no plano internacional como resposta às inúmeras barbaridades ocorridas até então.

\footnotetext{
${ }^{4}$ Arguição de Descumprimento de Preceito Fundamental no 54, Rel. Min. Marco Aurélio.
} 
Revista da Faculdade de Direito-RFD-UERJ - Rio de Janeiro, n. 31, jun. 2017

Deste modo, os principais diplomas internacionais que dizem respeito aos direitos humanos eclodiram depois da Segunda Guerra Mundial, tendo se destacado a Declaração Universal dos Direitos Humanos, aceita e proclamada pela Resolução no 217 A (III) da Assembleia Geral das Nações Unidas, em 10 de dezembro de 1948, e sido assinada pelo Brasil nesta mesma data.

Necessário salientar, todavia, que apesar de a referida Declaração ser tida como documento principal para os direitos humanos, a verdade é que o rol destes, em plano internacional, está colacionado, basicamente, na Carta Internacional dos Direitos Humanos que abrange também a Declaração Universal.

Nesta esteira, destaca Isabel Cabrita (2011, p. 50):

A lista dos direitos humanos está basicamente contida na Carta Internacional dos Direitos Humanos que é constituída pelas disposições sobre direitos humanos da Carta das Nações Unidas (v. Preâmbulo e artigos $1^{\circ}, 55^{\circ}$ e $56^{\circ}$ ), pela Declaração Universal dos Direitos do Homem, pelos Pactos Internacionais de Direitos Económicos, Sociais e Culturais (PIDESC) e de Direitos Civis e Políticos (PIDCP) e pelos Protocolos Facultativos aos dois Pactos.

Assim sendo, a Declaração Universal dos Direitos Humanos institui logo na sua introdução, ipsis litteris:

Considerando que os povos das Nações Unidas reafirmaram, na Carta, sua fé nos direitos humanos fundamentais, na dignidade e no valor da pessoa humana e na igualdade de direitos do homem e da mulher, e que decidiram promover o progresso social e melhores condições de vida em uma liberdade mais ampla.

Já em seu artigo $1^{\circ}$, in verbis:

Todas as pessoas nascem livres e iguais em dignidade e direitos. São dotadas de razão e consciência e devem agir em relação umas às outras com espírito de fraternidade.

Sobre o tema, Flávia Piovesan (2008, p. 137) explica: 


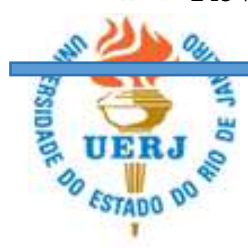

\begin{abstract}
A Declaração Universal de 1948 objetiva delinear uma ordem pública mundial fundada no respeito à dignidade humana, ao consagrar valores básicos universais. Desde seu preâmbulo, é afirmada a dignidade inerente a toda pessoa humana, titular de direitos iguais e inalienáveis. Vale dizer, para a Declaração Universal a condição de pessoa é o requisito único e exclusivo para a titularidade de direitos. A universalidade dos direitos humanos traduz a absoluta ruptura com o legado nazista, que condicionava a titularidade de direitos à pertinência à determinada raça (a raça pura ariana). A dignidade humana como fundamento dos direitos humanos e valor intrínseco à condição humana é concepção que, posteriormente, viria a ser incorporada por todos os tratados e declarações de direitos humanos, que passaram a integrar o chamado Direito Internacional dos Direitos Humanos.
\end{abstract}

Confirmando o que foi dito pela autora citada acima sobre o princípio da dignidade da pessoa humana como sendo o embasamento para a própria existência dos direitos humanos, a Declaração Universal de Direitos Humanos de 1948 também cita o referido princípio em muitas outras oportunidades, sendo que para ilustrar podemos citar o disposto nos artigos 22 e 23 , in verbis:

\footnotetext{
Art. 22: Toda a pessoa, como membro da sociedade, tem direito à segurança social; e pode legitimamente exigir a satisfação dos direitos econômicos, sociais e culturais indispensáveis, graças ao esforço nacional e à cooperação internacional, de harmonia com a organização e os recursos de cada país.

Art. 23: 1 - Toda a pessoa tem direito ao trabalho, à livre escolha do trabalho, a condições equitativas e satisfatórias de trabalho e à proteção contra o desemprego.

2 - Todos têm direito, sem discriminação alguma, a salário igual por trabalho igual.

3 - Quem trabalha tem direito a uma remuneração equitativa e satisfatória, que lhe permita e à sua família uma existência conforme com a dignidade humana, e completada, se possível, por todos os outros meios de proteção social.

4 - Toda a pessoa tem o direito de fundar com outras pessoas sindicatos e de se filiar em sindicatos para defesa dos seus interesses.
}

Dessa forma, enquanto o artigo 22 alude sobre os direitos econômicos, sociais e culturais, preconizando que estes precisam estar em consonância com a dignidade humana, o artigo 23 nos remete às exigências de um salário justo e satisfatório, o que garante à pessoa uma vida combatível com a dignidade humana.

Faz-se importante ressaltar, ademais, que a Declaração Universal dos Direitos Humanos foi criada não para ser um tratado internacional, mas sim uma recomendação, 
Revista da Faculdade de Direito-RFD-UERJ - Rio de Janeiro, n. 31, jun. 2017

não possuindo, no início, força obrigatória para os Estados. Todavia, a prática transtornou os regulamentos constantes em tal documento em costume internacional, sendo este fonte do Direito Internacional Público, de acordo com o assegurado no artigo 38 do Estatuto da Corte Internacional de Justiça.

Por essa razão, ainda que o Brasil não tivesse aderido ao Pacto Internacional dos Direitos Civis e Políticos (decreto $\mathrm{n}^{0} 592 / 92$ ), poderia ser forçado a acatar os ditames referentes à dignidade da pessoa humana com base na Declaração Universal de 1948.

Comungando deste entendimento, temos a opinião de Fábio Konder Comparato (2007, p. 227):

\begin{abstract}
Reconhece-se hoje, em toda parte, que a vigência dos direitos humanos independe de sua declaração em constituições, leis e tratados internacionais, exatamente porque se está diante de exigências de respeito à dignidade humana, exercidas contra todos os poderes estabelecidos, oficiais ou não. A doutrina jurídica contemporânea, de resto, como tem sido reiteradamente assinalado nesta obra, distingue os direitos humanos dos direitos fundamentais, na medida em que estes últimos são justamente os direitos humanos consagrados pelo Estado mediante normas escritas. É óbvio que a mesma distinção há de ser admitida no âmbito do direito internacional.
\end{abstract}

Assim sendo, mesmo não tendo sido firmada para ser um tratado com força cogente, de seguimento imperativo para os Estados, é manifesto o valor da Declaração Universal dos Direitos Humanos para o aprimoramento do princípio da dignidade da pessoa humana, tanto em sede internacional quanto em âmbito nacional nas Constituições dos Estados.

Noutro giro, a Declaração Americana dos Direitos e Deveres do Homem, também do ano de 1948, preconiza, em diversas oportunidades, o princípio da dignidade da pessoa humana.

Em que pese a referida declaração não ter conceituado literalmente o que seria dignidade da pessoa humana, em um determinado trecho ela nos dá a entender o que deve ser levado em conta na aferição de dignidade ${ }^{5}$, in verbis:

\footnotetext{
${ }^{5}$ A noção Kantiana de ser humano digno por natureza está pres ente nesta passagem da Declaração Americana.
} 
Que, em repetidas ocasiões, os Estados americanos reconheceram que os direitos essenciais do homem não derivam do fato de ser ele cidadão de determinado Estado, mas sim do fato dos direitos terem como base os atributos da pessoa humana.

Entretanto, a maior novidade trazida pela Declaração Americana dos Direitos e Deveres do Homem está na inserção dos deveres humanos. Neste sentido, o artigo 28 é um meio precioso de interpretação, ao afirmar, ipsis litteris:

Os direitos do homem estão limitados pelos direitos do próximo, pela segurança de todos e pelas justas exigências do bem-estar geral e do desenvolvimento democrático.

Ademais, a partir do segundo capítulo da Declaração Americana, mais especificamente a partir do artigo 29, passam a ser listados os deveres inerentes aos seres humanos, sendo alguns deles os deveres perante a sociedade, deveres para com os filhos e com os pais, deveres de instrução, deveres de sufrágio, etc.

Lado outro, o Pacto Internacional de Direitos Civis e Políticos, do ano de 1966, também se refere à dignidade humana:

Considerando que, em conformidade com os princípios proclamados na Carta das Nações Unidas, o reconhecimento da dignidade inerente a todos os membros da família humana e dos seus direitos iguais e inalienáveis constitui o fundamento da liberdade, da justiça e da paz no mundo. Reconhecendo que esses direitos decorrem da dignidade inerente à pessoa humana.

$\mathrm{O}$ artigo 10 de tal Pacto Internacional faz alusão direta ao princípio da dignidade da pessoa humana ao afirmar acerca do tratamento humano e digno para os que lidam com a privação de sua liberdade.

Toda pessoa privada de sua liberdade deverá ser tratada com humanidade e respeito à dignidade inerente à pessoa humana.

Igualmente no ano de 1966, a Organização das Nações Unidas também redigiu o Pacto Internacional de Direitos Econômicos, Sociais e Culturais, sendo que em tal documento a dignidade da pessoa humana é prevista nos considerandos, além de o artigo 13 a atrelar ao direito social da educação. 
Revista da Faculdade de Direito-RFD-UERJ - Rio de Janeiro, n. 31, jun. 2017

Hodiernamente, analisando-se estes e diversos outros diplomas internacionais, podemos afirmar que o íntegro incremento da dignidade da pessoa humana nos tratados internacionais relativos aos direitos humanos, faz com que, cada vez mais, tenhamos uma comunidade que zela pela fraternidade, justiça, igualdade e decência, onde os direitos inerentes aos seres humanos são acatados e as atrocidades, principalmente aquelas acontecidas durante a Alemanha nazista, no qual se pretendia exterminar todos aqueles que não fizessem parte da raça ariana, não são permitidas.

Para finalizar, os documentos internacionais de amparo aos seres humanos aqui citados servem, ainda, para reafirmar a essencialidade e o caráter basilar adquirido pelo princípio da dignidade da pessoa humana para a defesa, edificação e a proteção dos direitos fundamentais, os quais são garantidos pelo Estado às pessoas pelo simples fato de elas terem nascido com vida.

\section{O PRINCÍPIO DA DIGNIDADE DA PESSOA HUMANA E O DIREITO PENAL}

O campo do Direito onde ocorrem maiores interferências nos direitos fundamentais e, consequentemente, no princípio da dignidade da pessoa humana é, sem sombra de dúvidas, no Direito Penal. Por essa razão, imprescindível se torna a garantia de que a sanção criminal não infrinja esses direitos, garantindo a condição de ser humano inclusive para aqueles indivíduos que cometeram condutas criminosas e indignas.

Nesse contexto, temos as considerações de Ingo Wolfgang Sarlet (2007, p. 45):

[...] não se deverá olvidar que a dignidade - ao menos de acordo com o que parece ser a opinião largamente majoritária - independe das circunstâncias concretas, já que inerente a toda e qualquer pessoa humana, visto que, em princípio, todos - mesmo o maior dos criminosos - são iguais em dignidade, no sentido de serem reconhecidos como pessoas - ainda que não se portem de forma igualmente digna nas suas relações com seus semelhantes, inclusive consigo mesmos. Assim, mesmo que se possa compreender a dignidade da pessoa humana - na esteira do que lembra José Afonso da Silva - como forma de comportamento (admitindo-se, pois, atos dignos e indignos), ainda assim, exatamente por constituir - no sentido aqui acolhido - atributo intrínseco da pessoa humana (mas não propriamente inerente à sua natureza, 
como se fosse um atributo físico!) e expressar o seu valor absoluto, é que a dignidade de todas as pessoas, mesmo daquelas que cometem as ações mais indignas e infames, não poderá ser objeto de desconsideração.

Diante disso, a fim de traçar balizas à prática do poder punitivo estatal, todos os princípios penais, sem nenhuma exceção, devem traduzir a ideia de dignidade humana, ainda que pareça contraditório, tendo em vista as privações ocasionadas pela aplicação da pena, restringindo o ser humano de diversos direitos fundamentais, principalmente de sua liberdade.

Neste tópico, abordaremos, de forma apartada e sucinta, acerca dos principais princípios relativos à dignidade da pessoa humana com o Direito Penal, sendo que todos eles têm em comum o fato de estarem adstritos às limitações e diretrizes básicas estabelecidas na ordem constitucional.

\subsection{Princípio da presunção da inocência}

O princípio da presunção da inocência está inserido no inciso LVII do artigo $5^{\circ}$ da Constituição Federal de 1988, que dispõe que ninguém será considerado culpado até o trânsito em julgado de sentença penal condenatória.

Desse modo, a presunção da inocência é uma característica natural pertencente à condição da pessoa humana, independentemente da ocorrência de uma investigação ou de uma ação penal em curso. Assim, o ser humano nasce inocente até que seja provado, no bojo de um processo judicial, por meio de provas lícitas, com a observância do contraditório, ampla defesa e diversas outras garantias processuais, que o agente é culpado.

Salienta Luigi Ferrajoli (2010, p. 506) que:

A culpa, e não a inocência, deve ser demonstrada, e é a prova da culpa - ao invés da inocência, presumida desde o início - que forma o objeto do juízo.

Desse modo, o princípio em questão enfatiza a natureza virtuosa do ser humano, e não criminosa, sendo que ao pairar a dúvida acerca dos fatos, o estado de inocência 
Revista da Faculdade de Direito-RFD-UERJ - Rio de Janeiro, n. 31, jun. 2017

prevalecerá, pelo simples fato de que o agente nasce presumidamente inocente, cabendo ao órgão acusador provar a culpa do indivíduo.

Temos a opinião de Guilherme de Souza Nucci(2012, p. 264) sobre o tema:

[...] o estado natural do ser humano, seguindo-se fielmente o princípio da dignidade da pessoa humana, base do Estado Democrático de Direito, é a inocência. Inocente se nasce, permanecendo-se nesse estágio por toda a vida, a menos que haja o cometimento de uma infração penal e, seguindo-se os parâmetros do devido processo legal, consiga o Estado provocar a ocorrência de uma definitiva condenação criminal.

E também de AuryLopes Júnior (2011, p. 12):

Pode-se afirmar, com toda ênfase, que o princípio que primeiro impera no processo penal é o da proteção dos inocentes (débil), ou seja, o processo penal como direito protetor dos inocentes (e todos a ele submetidos o são, pois só perdem esse status após a sentença condenatória transitar em julgado), pois esse é o dever que emerge da presunção constitucional de inocência prevista no artigo $5^{\circ}$, LVII, da Constituição. O objeto primordial da tutela no processo penal é a liberdade processual do imputado, o respeito a sua dignidade como pessoa, como efetivo sujeito no processo.

Desse modo, inequívoco se torna a ligação entre o princípio da dignidade da pessoa humana e o princípio da presunção da inocência, uma vez que este garante a todos os indivíduos o direito de serem inocentes, em qualquer circunstância, a não ser que o Estado, por meio de sentença penal condenatória transitada em julgado, reconheça ser o agente culpado.

\subsection{Princípio da legalidade}

De acordo com o princípio da legalidade em sentido amplo, os indivíduos podem fazer tudo o que não estiver expressamente proibido em lei, podendo exercer livremente os seus direitos fundamentais. Em sentido estrito, o princípio em questão permite o conhecimento prévio dos delitos e das penas que serão aplicadas no caso de alguma conduta estabelecida no diploma penal como crime vir a ser praticada. 
Revista da Faculdade de Direito-RFD-UERJ - Rio de Janeiro, n. 31, jun. 2017

Neste último enfoque, somente as leis poderão estabelecer as sanções para os crimes, sendo que tais leis deverão ser fruto do Poder Legislativo, através do Congresso Nacional, representante autêntico e apropriado das vontades da sociedade.

Ainda em sentido estrito, o princípio da legalidade se manifesta pela locução nullum crime, nulla poena sine lege, e está previsto no artigo $5^{\circ}$, inciso XXXIX da Constituição Federal e no artigo $1^{\circ}$ do Código Penal. Tal princípio preceitua que não há crime sem lei anterior que o defina nem pena sem prévia cominação legal.

Desse modo, a legalidade é o princípio primário que decorre da dignidade da pessoa humana, tendo em vista que garante a liberdade, garantia elementar de todos os seres humanos, sendo, ademais, que a privação da liberdade do agente delituoso é, em nosso sistema jurídico, tratada como exceção.

Acerca do princípio da legalidade, o mestre Damásio Evangelista de Jesus (1991, p. 51) explica que:

O princípio da legalidade (ou da reserva legal) tem significado político, no sentido de uma garantia constitucional dos direitos do homem. Constitui uma garantia fundamental da liberdade civil, que não consiste em fazer tudo o que se quer, mas somente aquilo que a lei permite. A lei e somente ela pode fixar as limitações que destacam a atividade criminosa da atividade legítima. Esta é a condição de segurança e liberdade individual. Não haveria, com efeito, segurança ou liberdade se a lei a atingisse, para os punir, condutas lícitas quando praticadas, e se os juízes pudessem punir os fatos ainda não incriminados pelo legislador.

Desse modo, com a legalidade os indivíduos passam a desfrutar de direitos políticos em face da intervenção arbitrária do Estado em seus direitos fundamentais, dando-lhes segurança jurídica, vivendo conforme preceitua o princípio da dignidade da pessoa humana.

\subsection{Princípio da humanidade das penas}

O princípio da humanidade das penas encontra-se consubstanciado em nosso ordenamento jurídico no artigo $5^{\circ}$, inciso VLVII da Constituição Federal de 1988, onde fica estabelecido que: 
Art. $5^{\circ}$, XLVII: Não haverá penas:

a) de morte, salvo em caso de guerra declarada, nos termos do art. 84, XIX;

b) de caráter perpétuo;

c) de trabalhos forçados;

d) de banimento;

e) cruéis.

O princípio em tela advém diametralmente da dignidade, tendo em vista que o mesmo a reconhece ao proibir que a sanção seja utilizada como artifício de coisificação do ser humano, causando a este demasiado sofrimento físico e psíquico.

Sobre o tema, temos o entendimento de Helena Regina Lobo da Costa (2008, p. 65):

\begin{abstract}
Assim, o princípio da humanidade determina a proibição de penas que violem nuclearmente a vida, a integridade física e psíquica, a autonomia ou a igualdade de modo a subjugar a pessoa, destacando que, no que se refere à liberdade, este princípio determina que sua restrição deve ser limitada à liberdade de locomoção, respeitando-se a liberdade de pensamento, de crença, de ensino e qualquer outra expressão da liberdade que não seja abrangida pela restrição à liberdade de locomoção. Com efeito, o princípio da humanidade veda não apenas a pena de morte, mas também penas perpétuas ou de caráter perpétuo, em que não há esperança de reconquistar, por bom comportamento, a liberdade.
\end{abstract}

Michel Foucault (2002, p. 63) faz uma consideração conveniente ao afirmar que "no pior dos assassinos, uma coisa pelo menos deve ser respeitada quando punimos: sua 'humanidade". Por essa razão, por mais lastimável que tenha sido a conduta do delinquente, não se pode olvidar que, a despeito de tudo, trata-se de uma pessoa humana, devendo, por essa razão, ser tratada como assim sendo.

Portanto, a humanização consiste numa perspectiva mais socializada diante da sanção penal, não fazendo com que o apenado sofra um enorme suplício, nem perca seus direitos fundamentais e sua dignidade.

\title{
8.4 Princípio da intervenção mínima
}


Revista da Faculdade de Direito-RFD-UERJ - Rio de Janeiro, n. 31, jun. 2017

O princípio em tela estabelece que o Direito Penal deverá atuar somente em relação àqueles bens jurídicos que são indispensáveis à condição humana e à existência tranquila das pessoas em sociedade.

Dessa forma, o princípio da intervenção mínima nos remete ao aspecto subsidiário do Direito Penal, ou seja, tal ramo do Direito somente irá agir quando os outros ramos forem insuficientes, devendo o Direito Penal ser considerado como sendo a ultima ratio para a solução das desordens pré-existentes, afinal o mesmo possui contornos mais violentos, atingindo mais bruscamente os direitos $\mathrm{e}$ as garantias individuais dos seres humanos.

Temos as considerações de Francisco de Assis Toledo (1994, p. 17) acerca do princípio em questão:

Se a intervenção do Direito Penal só se faz diante da ofensa de um bem jurídico, nem todos os bens jurídicos se colocam a tutela específica do Direito Penal. Do ângulo penalístico, bem jurídico é aquele que esteja a exigir uma proteção especial, no âmbito da norma penal, por se revelarem insuficientes, em relação a ele, as garantias oferecidas pelo ordenamento jurídico em outras áreas extrapenais.

Importante ressaltar que o princípio da intervenção mínima se materializa no Direito brasileiro com a Declaração de Direitos do Homem e do Cidadão, mais especificamente em seu artigo $8^{\circ}$, in verbis:

A Lei apenas deve estabelecer penas estrita e evidentemente necessárias, e ninguém pode ser punido senão em virtude de uma lei estabelecida e promulgada antes do delito e legalmente aplicada.

Desse modo, torna-se imperioso afirmar que como o princípio em questão destina-se a minimizar a incidência de leis penais que estabeleçam crimes, interferindo, outrossim, o mínimo possível na esfera dos direitos fundamentais, o mesmo torna-se um desdobramento da dignidade da pessoa humana, sendo um limite ao jus puniendi do Estado em prol do ser humano. 
Revista da Faculdade de Direito-RFD-UERJ - Rio de Janeiro, n. 31, jun. 2017

É sabido que existem diversos outros princípios que estabelecem restrições ao poder de punir do Estado a fim de que seja preservado o valor máximo da dignidade humana, não sendo, todavia, finalidade do presente trabalho englobar o estudo de todos eles, mas apenas demonstrar que o jus puniendi estatal é limitado e relativo, existindo diversos limites que são importantes para que o Direito Penal se amolde aos ditames do Estado Democrático de Direito, pregado pela Constituição Federal de 1988, cujo fundamento precípuo é o da dignidade da pessoa humana.

\section{O PRINCÍPIO DA DIGNIDADE DA PESSOA HUMANA E O DIREITO DO TRABALHO}

É cediço que o princípio da dignidade da pessoa humana encontra respaldo em todos os ramos do Direito. Dessa forma, não poderia ser diferente no Direito do Trabalho, tendo em vista que é neste campo que são traçados os direitos e as garantias dos trabalhadores.

Nos dizeres de Gabriela Delgado (2006, p. 206):

[...] no desempenho das relações sociais, em que se destacam as trabalhistas, deve ser vedada a violação da dignidade, o que significa que o ser humano jamais poderá ser utilizado como objeto ou meio para a realização do querer alheio.

Importante ressaltar que a existência digna está intimamente ligada à valorização do trabalho, não existindo concretização total da dignidade humana se o trabalho não for devidamente valorizado.

Neste contexto, temos as palavras de José Felipe Ledur (1998, p. 98):

[...] a realização do direito ao trabalho fará com que a dignidade humana assuma nítido conteúdo social, na medida em que a criação de melhores condições de vida resultar benéfica não somente para o indivíduo em seu âmbito particular, mas para o conjunto da sociedade.

E continua o ilustre jurista (1998, p. 103): 
[...] as normas que garantem os direitos econômicos devem assegurar, de sua parte, o direito a um nível de vida decente, como expressão e realização desse princípio fundamental. [...] como primeiro princípio dos direitos fundamentais, ele (o princípio da dignidade da pessoa humana) não se harmoniza com a falta de trabalho justamente remunerado, sem o qual não é dado às pessoas prover adequadamente a sua existência, isto é, viver com dignidade.

Assim sendo, considerando que a valorização do trabalho é uma das diretrizes de concretização do princípio da dignidade da pessoa humana, nosso ordenamento jurídico estabelece diversos direitos e deveres aos trabalhadores, tendo ambos a finalidade de proteção dos mesmos, tendo em vista que os empregados são a parte mais fraca nas relações de natureza trabalhista, devendo, por essa razão, ter o amparo do Estado.

Nos tópicos seguintes abordaremos de forma separada e breve sobre os principais aspectos ligados à dignidade humana e o direito do trabalho, sempre tendo em vista que o Direito pátrio veda toda e qualquer forma de afronta aos direitos dos trabalhadores.

\subsection{Trabalho digno}

O trabalho em condições dignas é conseguido quando são garantidos aos seres humanos os direitos ínfimos de vencimento justo, de liberdade, de equidade e de segurança durante o vínculo laboral.

Brito Filho (2004, p. 61) afirma que:

Trabalho decente, então, é um conjunto mínimo de direitos do trabalhador que corresponde: à existência de trabalho; à liberdade de trabalho; à igualdade no trabalho; ao trabalho com condições justas, incluindo a remuneração, e que preservem sua saúde e segurança; à proibição do trabalho infantil; à liberdade sindical; e à proteção contra os riscos sociais.

Decorrem deste conceito os seguintes direitos do trabalhador: liberdade sindical, livre arbítrio na escolha do emprego, vedação à discriminação de qualquer natureza, salário justo, garantia do trabalho em boas condições, não sendo tolerada a sua sujeição a tratamentos humilhantes e vexatórios. Ademais, as normas relativas à saúde e 
Revista da Faculdade de Direito-RFD-UERJ - Rio de Janeiro, n. 31, jun. 2017

segurança do trabalho devem ser obedecidas, pois as mesmas asseguram aos trabalhadores a prática de seus afazeres em um recinto saudável e livre de elementos danosos à vida.

Assim, como o trabalho é o meio de fazer com que o ser humano promova seus talentos físicos e intelectuais, sendo, outrossim, forma de sustento financeiro, podemos afirmar que o trabalho é um direito que todos os indivíduos possuem. Todavia, dentro deste direito deriva o direito às condições dignas de trabalho, não podendo o ser humano tolerar nenhum tipo de serviço que não esteja em consonância com o princípio da dignidade da pessoa humana, sendo uma afronta a qualquer indivíduo condições desumanas e precárias de trabalho, garantindo-se, por essa razão, condições mínimas de existência e não de sobrevivência aos seres humanos.

\subsection{Não discriminação nas relações de trabalho}

Discriminar significa estabelecer diferenças, sendo contrário ao que determina o princípio da isonomia previsto no artigo $5^{\circ}$ da Constituição Federal de 1988, que preconiza que todos são iguais perante a lei, sem distinção de qualquer natureza.

Desse modo, discriminação é a ação de tratar os indivíduos de forma diferente e mais desfavorável a partir de certos atributos individuais, tais como o sexo, a raça, a cor, etc.

O princípio da não discriminação é aplicado no Direito do Trabalho como sendo um princípio protetor do trabalhador, cuja finalidade é colocar os empregados no mesmo patamar, evitando que existam diferenças entre eles nas relações laborais.

A não discriminação é um direito constitucionalmente assegurado aos trabalhadores no artigo $7^{\circ}$, incisos XXX, XXXII e XXXIII da Carta Magna, in verbis:

Art. $7^{\text {o: }}$ São direitos dos trabalhadores urbanos e rurais, além de outros que visem à melhoria de sua condição social:

XXX - proibição de diferença de salários, de exercício de funções e de critério de admissão por motivo de sexo, idade, cor ou estado civil;

XXXI - proibição de qualquer discriminação no tocante a salário e critérios de admissão do trabalhador portador de deficiência; 
Revista da Faculdade de Direito-RFD-UERJ - Rio de Janeiro, n. 31, jun. 2017

XXXII - proibição de distinção entre trabalho manual, técnico e intelectual ou entre os profissionais respectivos.

A Consolidação das Leis do Trabalho também traça diretrizes contra a discriminação:

Art. 5\%: A todo trabalho de igual valor corresponderá salário igual, sem distinção de sexo.

Art. 461: Sendo idêntica a função, a todo trabalho de igual valor, prestado ao mesmo empregador, na mesma localidade, corresponderá igual salário, sem distinção de sexo, nacionalidade ou idade.

A Organização Internacional do Trabalho, convenção devidamente ratificada pelo Brasil, conceitua discriminação do trabalho da seguinte forma:

Art. $1^{\text {o: }}$ Toda distinção, exclusão ou preferência fundada na raça, cor, sexo, religião, opinião política, ascendência nacional ou origem social que tenha por efeito destruir ou alterar a igualdade de oportunidades ou de tratamento em matéria de emprego ou profissão.

Desse modo, a discriminação faz com que haja a diminuição do valor da pessoa, fazendo com que a mesma se sinta psicologicamente abalada, tendo sua dignidade ferida, o que é inadmissível em nosso ordenamento jurídico, tendo em vista o princípio da igualdade, sendo todos os indivíduos iguais em direitos e obrigações, não existindo distinção de qualquer natureza.

A jurisprudência de nossos tribunais é pacífica neste sentido:

DISCRIMINAÇÃO NO TRABALHO. VEDAÇÃO CONSTITUCIONAL. RECURSO PARCIALMENTE PROVIDO. Demonstrado nos autos que o empregador discriminou os trabalhadores de nível técnico sem razão plausível, há que ser provido o recurso, sob pena de restar violado o $\operatorname{art} \mathbf{7}^{\circ}$, XXXII da CF/88. (TRT-7, Relator: ANTONIO CARLOS CHAVES ANTERO, Data de Julgamento: 11/07/2005, PLENO DO TRIBUNAL, grifo do autor).

PRINCÍPIO DA ISONOMIA OU DA NÃO-DISCRIMINAÇÃO. Evidente que o fornecimento do benefício vale-alimentação e vale-refeição não é uma obrigatoriedade legal e que, quando não previsto nas normas coletivas de forma coercitiva, caso dos autos, em que a cláusula quinquagésima oitava da Convenção Coletiva estabelece apenas obrigação facultativa, trata-se de mera liberalidade. Todavia, optando a empresa por fornecer os benefícios aos seus funcionários, deverá fazê-lo a todos igualmente, sob pena de afronta ao 
Revista da Faculdade de Direito-RFD-UERJ - Rio de Janeiro, n. 31, jun. 2017

\begin{abstract}
princípio da isonomia ou da não-discriminação, como bem referido na sentença. O princípio da não-discriminação no trabalho pressupõe que todo o trabalho de igual valor merece igual remuneração. $O$ propósito é coibir praticas repugnantes de discriminação no trabalho, sejam de natureza de raça, sexo, idade, crença religiosa ou de qualquer outra natureza. $\quad$ (TRT-4 - RO: 108506020115040271 RS 001085060.2011.5.04.0271, Relator: MARCELO GONÇALVES DE OLIVEIRA, Data de Julgamento: 22/08/2012, Vara do Trabalho de Osório, grifo do autor).
\end{abstract}

INTERVALO - ARTIGO 384 DA CLT. Não há razão para o tratamento diferenciado e não se pode admitir a diferenciação apenas em razão do sexo, pois se estaria estimulando a discriminação no trabalho entre iguais. A Constituição Federal, em seu art. $5^{\circ}$, I ao estabelecer a igualdade entre homens e mulheres em direitos e obrigações e proibir a diferença de salários, de exercício de funções e de critério de admissão por motivo de sexo, idade, cor ou estado civil (art. $7^{\circ}, \mathrm{XXX}$ ), não recepcionou o disposto no art. 384 da CLT. (TRT-3 - RO: 01216201206203004 000121678.2012.5.03.0062, Relator: Maria Stela Alvares da S.Campos, Nona Turma, Data de Publicação: 27/06/2013 25/06/2013. DEJT. Página 174. Boletim: Não, grifo do autor).

Portanto, a discriminação macula a dignidade da pessoa humana na medida em que atinge o princípio da igualdade, fazendo com que existam diferenças de cunhos pessoais em relações empregatícias, sendo totalmente abominável pelo Direito brasileiro.

\title{
9.3 Meio ambiente do trabalho
}

O direito ao meio ambiente é um direito fundamental, consagrado no artigo 225 da Constituição Federal de 1988, in verbis:

Todos têm direito a um meio ambiente ecologicamente equilibrado, bem de uso comum do povo e essencial a sadia qualidade de vida, impondo-se ao poder público e a coletividade o dever de defendê-lo e preservá-lo para as presentes e futuras gerações.

Partindo dessa premissa, podemos conceituar o meio ambiente do trabalho como sendo o local onde os trabalhadores exercem suas atividades laborativas com a qualidade necessária para tanto.

Na visão de José Afonso da Silva (2003, p. 5): 


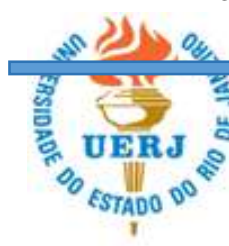

O meio ambiente do trabalho corresponde ao complexo de bens imóveis e móveis de uma empresa e de uma sociedade, objeto de direitos subjetivos privados, e de direitos invioláveis da saúde e da integridade física dos trabalhadores que o frequentam.

Nas considerações de Amauri Mascaro do Nascimento (2003, p. 63-584):

O meio ambiente de trabalho é, exatamente, o complexo máquina-trabalho; as edificações, do estabelecimento, equipamentos de proteção individual, iluminação, conforto térmico, instalações elétricas, condições de salubridade ou insalubridade, de periculosidade ou não, meios de prevenção à fadiga, outras medidas de proteção ao trabalhador, jornadas de trabalho e horas extras, intervalos, descansos, férias, movimentação, armazenagem e manuseio de materiais que formam o conjunto de condições de trabalho etc.

Já para Júlio Cesar de Sá da Rocha (2002, p. 30):

O meio ambiente do trabalho caracteriza-se como a ambiência na qual se desenvolvem as atividades do trabalho humano. Diante das modificações por que passa o trabalho, o meio ambiente laboral não se restringe ao espaço interno da fábrica ou da empresa, mas se estende ao próprio local de moradia ou ao ambiente urbano.

Dessa forma, o empregado tem o direito de trabalhar em um local onde haja condições de salubridade para tanto, não colocando em risco sua saúde e sua condição de pessoa humana, não podendo se aventurar em atividades que coloquem sua vida em risco.

Ademais, os utensílios manejados pelo trabalhador, o cumprimento dos afazeres, a forma na qual o empregado é tratado, tudo isso é considerado como sendo meio ambiente do trabalho.

Nesta esteira, temos os dizeres de Celso Antônio Pacheco Fiorillo (2013, p.29):

Em um ambiente onde os trabalhadores são maltratados, humilhados, perseguidos, ridicularizados, submetidos a exigências de tarefas abaixo ou acima de sua qualificação profissional, de tarefas inúteis ou ao cumprimento de metas impossíveis de atingimento, naturalmente haverá uma deterioração das condições de trabalho, com adoecimento do ambiente e das condições de trabalho, com extensão até para o ambiente familiar. Por tanto, o conceito de meio ambiente do trabalho deve levar em conta a pessoa do trabalhador e tudo que o cerca. 
Revista da Faculdade de Direito-RFD-UERJ - Rio de Janeiro, n. 31, jun. 2017

Por essa razão, podemos afirmar que o meio ambiente do trabalho é aquele em que dá as adequadas condições ao empregado de executar suas atividades, sem colocar em risco sua integridade física e psíquica.

Assim, o meio ambiente do trabalho deve ser condizente com a dignidade da pessoa humana, não podendo haver ausência de cautela por parte do empregador a fim de trazer prejuízos à vida do empregado.

Vejamos o entendimento jurisprudencial exarado pelo Tribunal Superior do Trabalho:

RECURSO DE REVISTA. INDENIZAÇÃO POR DANOS MATERIAL, MORAL E ESTÉTICO. ACIDENTE DE TRABALHO. FUNCCÃO DE MECÂNICO DE VEÍCULOS- QUEDA DA ENGRENAGEM DA -CAIXA REDUTORA DE CORREIA- SOBRE AS MÃOS. NEGLIGÊNCIA COM O MEIO AMBIENTE DO TRABALHO. CULPA PRESUMIDA. RECURSO DE REVISTA. INDENIZAČ̃̃O POR DANOS MATERIAL, MORAL E ESTÉTICO. ACIDENTE DE TRABALHO. FUNÇÃO DE MECÂNICO DE VEÍCULOS. QUEDA DA ENGRENAGEM DA -CAIXA REDUTORA DE CORREIA- SOBRE AS MÃOS. NEGLIGÊNCIA COM O MEIO AMBIENTE DO TRABALHO. CULPA PRESUMIDA. A preocupação da sociedade, no que se refere às questões correlatas ao meio ambiente, às condiç̃es de trabalho, à responsabilidade social, aos valores éticos e morais, bem como a dignidade da pessoa humana, exige do empregador estrita observância do princípio da precaução. Presume-se a culpa do empregador em face das circunstâncias ambientais adversas que deram origem ao acidente de trabalho. A responsabilidade do empregador, no caso, configura-se ante o fato de que a reclamada se absteve de prover os meios necessários a um ambiente de trabalho seguro a seus empregados, a acarretar a exposição do empregado a risco potencial de acidente de trabalho. Esse quadro é ainda reforçado pela conduta de risco da reclamada, que permitiu a atuação do reclamante sem o devido treinamento ou equipamento de trabalho. Assim, sua abstenção ou omissão acarreta o reconhecimento da responsabilidade pelo evento danoso ocorrido. Recurso de revista conhecido e provido. (TST - RR: 18824720115120003 188247.2011.5.12.0003, Relator: Aloysio Corrêa da Veiga, Data de Julgamento: 11/06/2013, $6^{a}$ Turma, Data de Publicação: DEJT 14/06/2013, grifo do autor).

Assim, o trabalhador faz jus às condições de trabalho dignas, devendo o empregador se ater às normas de segurança e medicina do trabalho, higiene, equipamentos de proteção individual, além de se abster de condutas que possam 
Revista da Faculdade de Direito-RFD-UERJ - Rio de Janeiro, n. 31, jun. 2017

envergonhar ou humilhar o empregado, conforme preconiza o princípio da dignidade da pessoa humana.

\section{CONCLUSÃO}

Conforme analisado no decorrer deste trabalho, o princípio da dignidade da pessoa humana funciona como um sustentáculo para todo o ordenamento jurídico brasileiro, estando presente em todos os ramos do Direito, preconizando que nenhum ser humano pode viver em condições que maculem sua dignidade.

Por essa razão, conclui-se que o princípio da dignidade da pessoa humana é um princípio basilar e supremo, que garante a todos os indivíduos, indistintamente, o pleno gozo dos direitos fundamentais, impondo limites ao poder estatal em todas as suas esferas, fazendo com que o ser humano seja protegido, tanto na criação das normas quanto em sua aplicação, dos abusos do Estado que venham a ferir sua dignidade.

Conforme foi mencionado, o princípio da dignidade da pessoa humana tem uma importância tão grande em nosso sistema jurídico que o mesmo passou a ser aplicado inclusive no campo do direito privado, tendo em vista que o Código Civil de 2002 prevê, em seu artigo 421, que a liberdade de contratar será exercida em razão e nos limites da função social do contrato. Ora, isso significa que até mesmo nas relações de direito privado a dignidade humana deve ser preservada, tendo o Código Civil de 2002 se adaptado à realidade consagrada pela Constituição Federal de 1988, que elevou o princípio da dignidade da pessoa humana a fundamento da República Federativa do Brasil.

Da mesma forma, o princípio da dignidade da pessoa humana ocupa um lugar tão privilegiado em nosso ordenamento jurídico que em apenas hipóteses remotas serão admitidas sua relativização, mas ainda assim, para que tal mitigação ocorra faz-se necessário que a dignidade humana se contraponha a algum outro princípio constitucional também de grande magnitude. Dessemodo, em todas as demais hipóteses o princípio da dignidade da pessoa humana irá prevalecer por tratar-se de uma norma garantidora de existência digna aos seres humanos, cuja aplicabilidade é incontestável. 
Revista da Faculdade de Direito-RFD-UERJ - Rio de Janeiro, n. 31, jun. 2017

Ademais, sendo a dignidade um atributo do homem, advinda do direito natural, a mesma não the pode ser tirada, devendo ser preservada até mesmo no ramo do Direito Penal, onde há a mitigação de inúmeros direitos fundamentais dos detentos, sendo o mais importante deles o direito à liberdade.

Desse modo, a restrição do direito à liberdade deve ser sempre dosada de acordo com o princípio da dignidade da pessoa humana, sendo, por esta razão, a segregação tratada como exceção em nosso ordenamento jurídico. Assim, as hipóteses de cabimento de prisões são taxativas pela lei penal, pois vigora em nosso sistema o direito à liberdade, que é a condição nata do ser humano.

Portanto, finalizamos o presente trabalho reiterando acerca do valor inconteste que o princípio da dignidade da pessoa humana possui, sendo ele uma verdadeira norma protetiva dos direitos humanos, pertencente a todos, independentemente de qualquer condição, significando que, como o ordenamento jurídico existe para os homens, nada mais justo que estes sejam os sujeitos primários e centrais de direitos, devendo todos viverem de acordo com o que determina o princípio da dignidade da pessoa humana.

\section{REFERÊNCIAS}

AMARAL, Francisco Piedade. Direito civil: introdução. 5.ed. Rio de Janeiro: Renovar, 2003.

AMARO, Luciano. Direito Tributário Brasileiro. 7.ed. São Paulo: Saraiva, 2001.

BARROSO, Luís Roberto. Fundamentos Teóricos e Filosóficos do Novo Direito Constitucional Brasileiro (Pós Modernidade, teoria crítica e pós-positivismo) In: Revista Diálogo Jurídico. Salvador, a. I, v. I, set. 2001.

BARROSO, Luís Roberto. $O$ direito constitucional e a efetividade de suas normas limites e possibilidades da Constituição Brasileira. 7.ed. Rio de Janeiro: Renovar, 2003.

BARROSO, Luís Roberto. Neoconstitucionalismo e constitucionalização do Direito. $O$ triunfo tardio do Direito Constitucional no Brasil. Jus Navigandi, Teresina, ano 10, n. 
Revista da Faculdade de Direito-RFD-UERJ - Rio de Janeiro, n. 31, jun. 2017

851, 1 nov. 2005. Disponível em: <http//jus.com. br/revista/texto/7547>. Acesso em: 17 set. 2015 .

BRASIL. Código Civil. Lei $\mathrm{n}^{\mathrm{o}} 3.071$, de $1^{\mathrm{o}}$ de janeiro de 1916. Disponível em: <http://www.planalto.gov.br/ccivil_03/leis/2002/110406.htm> Acesso em: 01 set. 2015.

BRASIL. Constituição da República Federativa do Brasil, de 05 de outubro de 1.988. Disponível em: http://www.planalto.gov.br/ccivil_03/Constituicao/Constituicao.htm> Acesso em 27 ago. 2015.

BRASIL. Código Penal. Lei $\mathrm{n}^{\mathrm{o}}$ 2.848, de 07 de dezembro de 1.940. Disponível em: <http://www.planalto.gov.br/ccivil_03/decreto-lei/Del2848compilado.htm> Acesso em 31 ago. 2015.

BRASIL. Lei $\mathrm{n}^{\mathrm{o}} 5.452$, de $1^{\mathrm{o}}$ de maio de 1943. Disponível em: <http:/www.planalto.gov.br/ccivil_03/decreto-lei/Del5452.htm> Acesso em 03 set. 2015.

BRITO FILHO, José Cláudio Monteiro de. Trabalho decente. Análise jurídica da exploração do trabalho - trabalho forçado e outras formas de trabalho indigno. São Paulo: LTr, 2004.

BONAVIDES, Paulo. Teoria Constitucional da Democracia Participativa. São Paulo: Malheiros, 2001.

CABRITA, Isabel. Direitos humanos: um conceito em movimento. Coimbra: Almedina, 2011.

CANOTILHO, José Joaquim Gomes. Direito constitucional. 5.ed. Coimbra: Almedina, 2002.

CARNEIRO, Cláudio. Curso de Direito Financeiro e Tributário. 17.ed. Rio de Janeiro: Lumem Juris, 2010.

CARRAZZA, Roque Antônio. Curso de Direito Constitucional Tributário. 26.ed. São Paulo: Malheiros Editora, 2010.

CARVALHO, Kildare Gonçalves Carvalho. Direito Constitucional. 13.ed. Belo Horizonte: Del Rey, 2007. 
Revista da Faculdade de Direito-RFD-UERJ - Rio de Janeiro, n. 31, jun. 2017

COMPARATO, Fábio Konder. A Afirmação Histórica dos Direitos Humanos. 5.ed. São

Paulo: Saraiva, 2007.

COSTA, Helena Regina Lobo da.A dignidade humana: teorias de prevenção geral positiva. São Paulo: Revista dos Tribunais, 2008.

DELGADO, Gabriela. Direito Fundamental ao Trabalho digno. São Paulo: LTr, 2006.

DIMOULIS, Dimitri MARTINS, Leonardo. Teoria geral dos direitos fundamentais ob. cit., 2007.

ESPÍNDOLA, Ruy Samuel. Conceito de princípios constitucionais. São Paulo: Revista dosTribunais, 1998.

FERRAJOLI, Luigi. Direito e razão - teoria do garantismo penal. 3.ed. São Paulo: Editora Revista dos Tribunais, 2010.

FIORILlO, Celso Antônio Pacheco. Curso de direito ambiental. 14.ed. São Paulo: Saraiva, 2013.

FIORILlO, Celso Antônio Pacheco. $O$ direito de antena em face do direito ambiental no Brasil. São Paulo: Saraiva, 2000.

FOUCAULT, Michel. Vigiar e punir: nascimento da prisão. Trad. de Raquel Ramalhete. Petrópolis: Vozes, 1987.

GOLDSCHMIDT, Fabio Brun. O princípio do não confisco no direito tributário. São Paulo: RT, 2003.

HOUAISS, Antônio; VILLAR, Mauro de Salles. Minidicionário Houaiss de língua portuguesa. 2. ed. Rio de Janeiro: Objetiva, 2004.

JESUS, Damásio Evangelista. Direito Penal - Parte Geral. 15.ed. São Paulo: Saraiva, 1991.

KRELL, Andreas Joachim. Direitos Sociais e Controle Judicial no Brasil e na Alemanha: os descaminhos de um direito constitucional "comparado". Porto Alegre: Sérgio A. Fabris, 2002. 
Revista da Faculdade de Direito-RFD-UERJ - Rio de Janeiro, n. 31, jun. 2017

LEDUR, José Felipe. A realização do Direito ao Trabalho. Porto Alegre: Sérgio Antônio Fabris Editor, 1998.

LENZA,Pedro. Direito Constitucional Esquematizado. 14.ed. Editora Saraiva, 2010.

LIMA, Herotides da Silva. O emprego de algemas. Revista do Departamento de Investigações, ano I, São Paulo: s.e., fev. 1949.

LOPES JR., Aury. Direito processual penal e sua conformidade constitucional. Vol. I. 7. ed. Rio de Janeiro: Lumen Juris, 2011.

MAXIMILIANO, Carlos. Hermenêutica e aplicação do direito. 16.ed. Rio de Janeiro: Forense, 1997.

MELlO, Celso Antônio Bandeira de. Curso de Direito Administrativo, 15.ed. São Paulo, Malheiros, 2003.

MENDES, Gilmar Ferreira. Curso de Direito Constitucional. Brasilia: Saraiva, 2009.

MORAIS, Alexandre de. Direito Constitucional. 16.ed. São Paulo: Atlas, 2004.

NASCIMENTO, Amauri Mascaro do. A defesa processual do meio ambiente do trabalho. Revista LTr, 2003.

NORONHA, Fernando. $O$ direito dos contratos e seus princípios fundamentais: autonomia privada, boa-fé, justiça contratual. São Paulo: Saraiva, 1994.

NUCCI, Guilherme de Souza. Princípios constitucionais penais e processuais penais. 2.ed. São Paulo: Editora Revista dos Tribunais, 2012.

PIOVESAN, Flávia. Temas de Direitos Humanos. 3.ed. São Paulo: Saraiva, 2009. 
Revista da Faculdade de Direito-RFD-UERJ - Rio de Janeiro, n. 31, jun. 2017

PIOVESAN, Flávia. Direitos Humanos e o Direito Constitucional Internacional. 9.ed. São Paulo: Saraiva, 2008.

REALE, Miguel. Filosofia do Direito. 23.ed. São Paulo: Saraiva, 1999.

ROCHA, Júlio César de Sá da.A defesa processual do meio ambiente do trabalho: dano, prevenção e proteção jurídica. São Paulo, Ed. LTr, 2002.

SABBAG, Eduardo. Manual de Direito Tributário. 3.ed. São Paulo: Saraiva, 2011.

SABBAG, Eduardo. Manual de Direito Tributário. 2.ed. São Paulo: Saraiva, 2010.

SANTOS, Manoel Lourenço dos. Direito tributário. 3.ed. Rio de Janeiro: Fundação Getúlio Vargas, 1970.

SARLET, Ingo Wolfgang. A eficácia dos direitos fundamentais. 8. ed. Porto Alegre: Editora Livraria do Advogado, 2007.

SARLET, Ingo Wolfgang. Dignidade da pessoa humana e direitos fundamentais na Constituição Federal de 1988. Porto Alegre: Livraria dos Advogados, 2004.

SARLET, Ingo Wolfgang Sarlet. Dignidade da Pessoa Humana e Direitos Fundamentais na Constituição Federal de 1988. 9.ed. Porto Alegre: Livraria do Advogado Editora, 2011.

SARLET, Ingo Wolfgang. Dignidade da Pessoa Humana e Direitos Fundamentais na Constituição Federal de 1988. 6. ed. Porto Alegre: Livraria do Advogado, 2008.

SARLET, Ingo Wolfgang. Dignidade da pessoa humana e direitos fundamentais na Constituição Federal de 1988. 5. ed. Porto Alegre: Livraria do Advogado, 2007.

SILVA, José Afonso da.Direito ambiental constitucional. 2.ed., São Paulo: Malheiros, 2003.

SILVA, José Afonso da. Poder Constituinte e Poder Popular: estudos sobre a Constituição. 1.ed. São Paulo: Malheiros, 2007. 
Revista da Faculdade de Direito-RFD-UERJ - Rio de Janeiro, n. 31, jun. 2017

SPINELI, Ana Claudia Marassi. Dos direitos da personalidade e o princípio da dignidade humana. Maringá: Centro Universitário de Maringá: Revista Jurídica do Cesumar Mestrado, 2008.

TOLEDO, Francisco de Assis. Princípios Básicos de Direito Penal. 5.ed. São Paulo: Saraiva, 1994.

TORRES, Andreza Cristina Baggio. Direito civil-constitucional: a função social do contrato e a boa-fé objetivas como limites à autonomia privada. In: Contrato \& Sociedade: princípios de direito contratual. v. II. Paulo Roberto Ribeiro Nalin (coord.) Curitiba: Juruá, 2006. 